SHORT ARTICLE

\title{
THE EFFECT OF HOMOGENISING TISSUES EITHER BEFORE OR AFTER STORAGE ON THE ISOLATION OF CHLAMYDIA TRACHOMATIS
}

\author{
P. FALDER, M. TUFFREY AND D. TAYLOR-ROBINSON \\ Division of Sexually Transmitted Diseases, MRC Clinical Research Centre, Watford Road, \\ Harrow, Middlesex HA1 $3 U J$
}

\begin{abstract}
Summary. To determine whether freezing before homogenisation or the reverse procedure was the best way of achieving maximal recovery of chlamydiae from solid tissues, specimens from mice infected experimentally with Chlamydia trachomatis were used. For 10 of 12 mice, three-fold to over fifty-fold more chlamydiae were isolated from portions of spleens which were homogenised before freezing in liquid nitrogen than from those which were homogenised after being stored frozen. The value of homogenising small strips of infected genital tissue before freezing was less apparent. Nevertheless, if this was undertaken, the number of chlamydiae recovered from the tissues of four of 10 mice was three-fold to seven-fold more than if the tissues were homogenised after freezing.
\end{abstract}

\section{INTRODUCTION}

Chlamydia trachomatis infection in women is a cause of cervicitis, endometritis and salpingitis that may lead to subsequent infertility problems (Taylor-Robinson and Thomas, 1980). Furthermore, the possibility that it may cause spontaneous abortion is of major interest. In most studies, the rate of isolation of chlamydiae has been determined from specimens taken by swabbing mucosal surfaces, but it may also be necessary to determine the presence and number of organisms within tissue pieces, e.g., endometrial curettings. We were concerned to know whether freezing before homogenisation or the reverse procedure was the best way of dealing with the latter specimens before attempts to isolate chlamydiae by inoculation of McCoy-cell cultures and we have used infected mouse tissues as a model to determine the way in which maximal recovery of chlamydiae could be achieved.

\section{MATERIALS AND MethodS}

Mice. Specific pathogen-free inbred female animals of the $\mathrm{CBA} / \mathrm{Ca} / \mathrm{CRC}$ sub-line and outbred female TO mice maintained by the minimal inbreeding system were used.

C. trachomatis strain. The 'fast' egg-killing human strain of $C$. trachomatis, designated $\mathrm{SA}_{2} \mathrm{f}$, was used. This is a genital strain which has been identified as an LGV-2 serotype.

Infection of mice. Twelve CBA animals were given $5 \times 10^{5}$ inclusion-forming units (ifu) of $\mathrm{SA}_{2} \mathrm{f}$ by intravenous injection. Additionally, $10 \mathrm{TO}$ mice each received $2.5 \mathrm{mg}$ of the progesterone preparation Depo-Provera (Upjohn) in two subcutaneous doses, one a week before and the other at the time of chlamydial inoculation. This prevented the onset of oestrous and enhanced the genital infection (Tuffrey and Taylor-Robinson, 1981). The TO mice were anaesthetised with pento-barbitone given intraperitoneally $(0.01 \mathrm{ml}$ of a ten-fold dilution of Sagatal per $\mathrm{g}$ body weight) and the uterus was exposed through a small lateral incision over the ovarian fat pad. The organisms $\left(1 \times 10^{5}\right.$ ifu) were inoculated directly into the uterine cavity through a 30 -gauge needle; the peritoneum was closed with a fine silk suture and the skin with a surgical clip.

Collection of specimens. Mice given intravenous inocula were killed 4, 5 and 6 days later. Each spleen was removed aseptically and cut in half. One half was homogenised in a 
ground-glass homogeniser in $2 \mathrm{ml}$ of sucrose-phosphate transport medium which contained $10 \%$ fetal calf serum (2SP). The other half was placed whole in $2 \mathrm{ml}$ of $2 \mathrm{SP}$ medium. All the samples were then stored in liquid nitrogen.

The vaginas of mice given genital inocula were swabbed with sterile cotton-wool nasopharyngeal swabs (Medical Wire and Equipment Co. Ltd) 5 days later and each swab was expressed in $1 \mathrm{ml}$ of 2SP medium which was then stored in liquid nitrogen. These mice were killed $8,13,14,15,19,20$ and 21 days after inoculation, and the genital tracts were dissected out. Each of the infected and non-infected uterine horns, plus the uterine body, cervix and vagina were cut longitudinally into half with a fine scalpel. One half of each tissue from each mouse was homogenised in $2 \mathrm{ml}$ of $2 \mathrm{SP}$ medium. The other half was placed in $2 \mathrm{ml}$ of $2 \mathrm{SP}$ medium and was not homogenised. All the samples were then stored in liquid nitrogen.

Isolation of chlamydiae. The solid and homogenised tissues were removed from liquid nitrogen at the same time and thawed at $37^{\circ} \mathrm{C}$, after which the solid specimens were homogenised in their existing medium. Then all the homogenates were added to $6 \mathrm{ml}$ of McCoy cell maintenance medium supplemented with glucose and antibiotics (Thomas et al., 1977), and the whole centrifuged at $600 \mathrm{~g}$ for $10 \mathrm{~min}$ to remove debris. The supernatant fluid was inoculated into six cycloheximide-treated McCoy-cell cultures which were incubated at $37^{\circ} \mathrm{C}$ for $48 \mathrm{~h}$ before being stained with Giemsa reagent to detect first cycle chlamydial inclusions (Thomas et al., 1977). The vaginal swab specimens, taken to confirm infection of the genital tract, were thawed and each was inoculated into two cell cultures.

\section{RESULTS}

The results of attempts to isolate chlamydiae from samples of tissue which had been homogenised, either before or after storage in liquid nitrogen, are shown in tables I and II.

\section{Isolation from the spleen}

Many more chlamydiae were isolated from portions of spleen which had been homogenised before storage than from those subjected to the reverse procedure (table I). For two mice, the difference between the numbers of chlamydiae isolated from portions of spleen subjected to the two procedures was minimal. However, for $10 \mathrm{mice}$, three-fold to over fifty-fold more chlamydiae were isolated from freshly homogenised specimens than from specimens which were homogenised after being stored frozen.

\section{Isolation from the genital tract}

Chlamydiae were isolated from all of the vaginal specimens taken 5 days after genital inoculation of chlamydiae. The organisms were isolated from the genital-tract tissues of all the mice given genital inocula, although the value of homogenisation before storage in liquid nitrogen was less apparent than with the spleens. Nevertheless, the number of organisms recovered from the tissues of four of the 10 mice was three-fold to seven-fold more when the tissues had been homogenised before than when they had been homogenised after storage.

\section{Discussion}

It is clear from these results that larger numbers of chlamydiae were isolated from samples which had been homogenised before storage in liquid nitrogen than from those homogenised after storage. The most striking results were obtained in tests on the spleen samples, probably because they were larger than the strips of genital-tract tissue, thus making penetration of the cryopreservative more difficult. However, half a mouse spleen is usually less than $5 \times 10 \mathrm{~mm}$, and is probably comparable in size to many pieces of human tissue that need to be investigated. Despite the small size of tissue pieces from the mouse genital tract, strips of which were only a few millimetres wide, larger numbers of chlamydiae were often recovered from material which had been freshly homogenised. It would, therefore, seem logical, when taking samples of human tissue for attempted chlamydial isolation, to ensure that the specimens are freshly homogenised 
TABLE I

The numbers of inclusions found in tests on spleens from twelve CBA mice given intravenous inocula of chlamydiae

\begin{tabular}{|c|c|c|c|c|}
\hline Mouse no. & $\begin{array}{l}\text { Treatment } \\
\text { (per half } \\
\text { spleen) }\end{array}$ & $\begin{array}{c}\text { Range of numbers } \\
\text { of ifu in } \\
2-6 \text { monolayers }\end{array}$ & $\begin{array}{c}\text { Average number } \\
\text { of ifu }\end{array}$ & $\begin{array}{c}\text { Approximate fold } \\
\text { increase in } \\
\text { number of ifu } \\
\text { by } H / F \text { treatment }\end{array}$ \\
\hline 1 & $\begin{array}{l}\mathrm{H} / \mathrm{F} \\
\mathrm{F} / \mathrm{H}\end{array}$ & $\begin{array}{l}5300-6300 \\
4100-5100\end{array}$ & $\begin{array}{l}5733 \\
4566\end{array}$ & \\
\hline 2 & $\begin{array}{l}\mathrm{H} / \mathrm{F} \\
\mathrm{F} / \mathrm{H}\end{array}$ & $\begin{array}{l}9200-10600 \\
1600-2700\end{array}$ & $\begin{array}{r}10000 \\
1966\end{array}$ & 5 \\
\hline 3 & $\begin{array}{l}\mathrm{H} / \mathrm{F} \\
\mathrm{F} / \mathrm{H}\end{array}$ & $\begin{array}{l}6739-11700 \\
1505-3000\end{array}$ & $\begin{array}{l}9446 \\
2421\end{array}$ & 4 \\
\hline 4 & $\begin{array}{l}\mathrm{H} / \mathrm{F} \\
\mathrm{F} / \mathrm{H}\end{array}$ & $\begin{array}{l}8900,11000 \\
2500-4303\end{array}$ & $\begin{array}{l}9950 \\
3234\end{array}$ & 3 \\
\hline 5 & $\begin{array}{l}\mathrm{H} / \mathrm{F} \\
\mathrm{F} / \mathrm{H}\end{array}$ & $\begin{array}{cl}2100, & 3300 \\
50, & 88\end{array}$ & $\begin{array}{r}2700 \\
69\end{array}$ & 39 \\
\hline 6 & $\begin{array}{l}\mathrm{H} / \mathrm{F} \\
\mathrm{F} / \mathrm{H}\end{array}$ & $\begin{array}{ll}250, & 368 \\
166, & 323\end{array}$ & $\begin{array}{l}309 \\
241\end{array}$ & \\
\hline 7 & $\begin{array}{l}\mathrm{H} / \mathrm{F} \\
\mathrm{F} / \mathrm{H}\end{array}$ & $\begin{aligned} 1300, & 2700 \\
23, & 54\end{aligned}$ & $\begin{array}{r}2000 \\
39\end{array}$ & 51 \\
\hline 8 & $\begin{array}{l}\mathrm{H} / \mathrm{F} \\
\mathrm{F} / \mathrm{H}\end{array}$ & $\begin{array}{c}2600-3000 \\
48-406\end{array}$ & $\begin{array}{r}2800 \\
232\end{array}$ & 12 \\
\hline 9 & $\begin{array}{l}\mathrm{H} / \mathrm{F} \\
\mathrm{F} / \mathrm{H}\end{array}$ & $\begin{array}{c}680-720 \\
39-62\end{array}$ & $\begin{array}{r}700 \\
51\end{array}$ & 14 \\
\hline 10 & $\begin{array}{l}\mathrm{H} / \mathrm{F} \\
\mathrm{F} / \mathrm{H}\end{array}$ & $\begin{array}{ll}410, & 429 \\
154, & 165\end{array}$ & $\begin{array}{l}420 \\
160\end{array}$ & 3 \\
\hline 11 & $\begin{array}{l}\mathrm{H} / \mathrm{F} \\
\mathrm{F} / \mathrm{H}\end{array}$ & $\begin{array}{r}680-720 \\
89, \quad 181\end{array}$ & $\begin{array}{l}700 \\
135\end{array}$ & 5 \\
\hline 12 & $\begin{array}{l}\mathrm{H} / \mathrm{F} \\
\mathrm{F} / \mathrm{H}\end{array}$ & $\begin{aligned} 500- & 514 \\
27, & 41\end{aligned}$ & $\begin{array}{r}507 \\
34\end{array}$ & 15 \\
\hline
\end{tabular}

$\mathrm{H} / \mathrm{F}=$ Homogenised then frozen; $\mathrm{F} / \mathrm{H}=$ Frozen whole, then homogenised.

TABLE II

The numbers of inclusions found in tests on genital-tract tissues from ten progesterone-treated TO mice given chlamydiae via the intrauterine route

\begin{tabular}{|c|c|c|c|c|}
\hline Mouse no. & $\begin{array}{c}\text { Treatment } \\
\text { (per half } \\
\text { genital } \\
\text { tract) }\end{array}$ & $\begin{array}{c}\text { Range of numbers } \\
\text { of ifu in } \\
2-6 \text { monolayers }\end{array}$ & $\begin{array}{l}\text { Average number } \\
\text { of ifu }\end{array}$ & $\begin{array}{c}\text { Approximate fold } \\
\text { increase in number } \\
\text { of ifu by } \\
H / F \text { treatment }\end{array}$ \\
\hline 1 & $\begin{array}{l}\mathrm{H} / \mathrm{F} \\
\mathrm{F} / \mathrm{H}\end{array}$ & $\begin{array}{lr}600, & 618 \\
247-824\end{array}$ & $\begin{array}{l}609 \\
530\end{array}$ & \\
\hline 2 & $\begin{array}{l}\mathrm{H} / \mathrm{F} \\
\mathrm{F} / \mathrm{H}\end{array}$ & $\begin{array}{r}1179-1234 \\
185-295\end{array}$ & $\begin{array}{r}1206 \\
238\end{array}$ & 5 \\
\hline 3 & $\begin{array}{l}\mathrm{H} / \mathrm{F} \\
\mathrm{F} / \mathrm{H}\end{array}$ & $\begin{array}{ll}28- & 93 \\
25- & 63\end{array}$ & $\begin{array}{l}53 \\
47\end{array}$ & \\
\hline 4 & $\begin{array}{l}\mathbf{H} / \mathbf{F} \\
\mathbf{F} / \mathbf{H}\end{array}$ & $\begin{array}{l}132-185 \\
188-330\end{array}$ & $\begin{array}{l}154 \\
256\end{array}$ & \\
\hline 5 & $\begin{array}{l}\mathbf{H} / \mathbf{F} \\
\mathbf{F} / \mathbf{H}\end{array}$ & $\begin{array}{l}1 \\
1\end{array}$ & $\begin{array}{l}1 \\
1\end{array}$ & \\
\hline 6 & $\begin{array}{l}\mathbf{H} / \mathbf{F} \\
\mathrm{F} / \mathrm{H}\end{array}$ & $\begin{array}{r}148-223 \\
35-\quad 49\end{array}$ & $\begin{array}{r}180 \\
42\end{array}$ & 4 \\
\hline 7 & $\begin{array}{l}\mathrm{H} / \mathrm{F} \\
\mathrm{F} / \mathrm{H}\end{array}$ & $\begin{array}{lr}99-141 \\
37-\quad 50\end{array}$ & $\begin{array}{r}118 \\
42\end{array}$ & 3 \\
\hline 8 & $\begin{array}{l}\mathrm{H} / \mathrm{F} \\
\mathrm{F} / \mathrm{H}\end{array}$ & $\begin{array}{ll}22- & 28 \\
16- & 27\end{array}$ & $\begin{array}{l}25 \\
21\end{array}$ & \\
\hline 9 & $\begin{array}{l}\mathrm{H} / \mathrm{F} \\
\mathrm{F} / \mathrm{H}\end{array}$ & $\begin{array}{ll}13- & 30 \\
15- & 19\end{array}$ & $\begin{array}{l}23 \\
17\end{array}$ & \\
\hline 10 & $\begin{array}{l}\mathrm{H} / \mathrm{F} \\
\mathrm{F} / \mathrm{H}\end{array}$ & $\begin{array}{rr}51- & 87 \\
2- & 16\end{array}$ & $\begin{array}{r}65 \\
9\end{array}$ & 7 \\
\hline
\end{tabular}

$\mathrm{H} / \mathrm{F}=$ Homogenised then frozen; $\mathrm{F} / \mathrm{H}=$ frozen whole, then homogenised. 
before storage. This practice would maximise the sensitivity of the chlamydial isolation technique.

\section{REFERENCES}

Taylor-Robinson D, Thomas B J 1980 The role of Chlamydia trachomatis in genital-tract and associated diseases. Journal of Clinical Pathology 33:205-233.

Thomas B J, Evans R T, Hutchinson G R, Taylor-Robinson D 1977 Early detection of chlamydial inclusions combining the use of cycloheximide-treated McCoy cells and immunofluorescence staining. Journal of Clinical Microbiology 6:285-292.

Tuffrey M, Taylor-Robinson D 1981 Progesterone as a key factor in the development of a mouse model for genital-tract infection wth Chlamydia trachomatis. FEMS Microbiology Letters $12: 111-115$. 